\title{
Natural and anthropogenic lead in sediments of the Rotorua lakes, New Zealand
}

\author{
L. K. Pearson ${ }^{a}$, C. H. Hendy ${ }^{a}$, D. P. Hamilton ${ }^{b}$ and R.C. Pickett ${ }^{a, 1}$ \\ ${ }^{a}$ Chemistry Department, University of Waikato, Private Bag 3105, Hamilton 3240, New Zealand. \\ ${ }^{b}$ Department of Biological Sciences, University of Waikato, Private Bag 3105, Hamilton 3240, New \\ Zealand. \\ ${ }^{1}$ Current address: Tonkin and Taylor Ltd, 105 Carlton Gore Road, Auckland 1023, New Zealand.
}

\section{Corresponding Author}

Lisa Pearson

Postal address: Chemistry Department, University of Waikato, Private Bag 3105, Hamilton 3240, New Zealand

Email address: $1 \mathrm{kp} 6 @$ waikato.ac.nz

Telephone: +64078565074

Fax: +64073834219

\begin{abstract}
Global atmospheric sources of lead have increased more than 100-fold over the past century as a result of deforestation, coal combustion, ore smelting and leaded petroleum. Lead compounds generally accumulate in depositional areas across the globe where, due to low solubility and relative freedom from microbial degradation, the history of their inputs is preserved. In lakes there is rapid deposition and often little bioturbation of lead, resulting in an excellent depositional history of changes in both natural and anthropogenic sources. The objective of this study was to use sediments from a regionally bounded set of lakes to provide an indication of the rates of environmental inputs of lead whilst taking into account differences of trophic state and lead exposure between lakes. Intact sediment gravity cores were collected from 13 Rotorua lakes in North Island of New Zealand between March 2006 and January 2007. Cores penetrated sediments to a depth of $16-30 \mathrm{~cm}$ and contained volcanic tephra from the 1886 AD Tarawera eruption. The upper depth of the Tarawera tephra enabled prescription of a date for the associated depth in the core (120 years). Each core showed a sub-surface peak in lead concentration above the Tarawera tephra which was contemporaneous with the peak use of lead alkyl as a petroleum additive in New Zealand. An $8 \mathrm{~m}$ piston core was taken in the largest of the lakes, Lake Rotorua, in March 2007. The lake is antipodal to the pre-industrial sources of atmospheric lead but still shows increasing lead concentrations from $<2$ up to $3.5 \mu \mathrm{g} \mathrm{g}^{-1}$ between the Whakatane eruption (5530 \pm 60 cal. yr BP) and the Tarawera eruption. Peaks in lead concentration in Lake Rotorua are associated with volcanic tephras, but are small compared with those arising from recent anthropogenic-derived lead deposition. Our results show that diagenetic processes associated with iron, manganese and sulfate
\end{abstract}


oxidation-reduction, and sulfide precipitation, act to smooth distributions of lead from anthropogenic sources in the lake sediments. The extent of this smoothing can be related to changes in sulfate availability and reduction in sulfide driven by differences in trophic status amongst the lakes. Greatest lead mobilisation occurs in mesotrophic lakes during seasonal anoxia as iron and manganese are released to the porewater, allowing upward migration of lead towards the sediment-water interface. This lead mobilisation can only occur if sulfides are not present. The sub-surface peak in lead concentrations in lake sediments ascribed to lead alkyl in petroleum persists despite the diagenetic processes acting to disperse lead within the sediments and into the overlying water.

\section{Keywords}

Lead alkyls, petroleum, trophic status, tephra, sedimentation rates

\section{Introduction}

Lead has a long residence time in the environment compared with most other pollutants (Davies, 1990; Nriagu, 1998). Natural sources of lead include particulates transported to lake sediments directly from erosion of sediments in the catchment, mobilisation of lead from the weathering of catchment bedrock and soils (Renberg et al., 2002), and atmospheric inputs from volcanic eruptions (Graney et al., 1995). Historically, the natural airborne lead fraction has been insignificant compared with supply from catchments (Bindler et al., 2001). With increasing anthropogenic additions of lead to the natural environment it has been possible to distinguish anthropogenic sources in disparate environments such as the Arctic (Sturges and Barrie, 1989), Pacific Ocean atmosphere (Settle and Patterson,1982), Antarctic and Greenland ice (Murozumi et al., 1969; Rosman et al., 1993; Hong et al., 1994), peat bogs (Shotyk et al., 1998), Alantic and Pacific Ocean corals (Shen and Boyle, 1987), coastal marine sediments (Chow et al., 1973; Veron et al., 1987) and lake sediments (Edgington and Robbins, 1976; Graney et al., 1995; Monna et al., 1999; Renberg et al., 2002). In these studies, isotopic ratios and/or changes in concentrations of lead have been used to infer a variety of different sources. Local emissions from industrial and urban sources dominate the lead found in lake sediments (Monna et al., 1999; Harrison and Laxen, 1984). In New Zealand, the only significant, broadscale anthropogenic source of lead is from petroleum additives. In the absence of natural environmental fluctuations, variations in lead within recent lake sediments should reflect changes in anthropogenic sources, whilst variations amongst lakes may reflect complex interactions with the environmental conditions leading to net deposition to the sediments.

In New Zealand lead alkyls were first added to petroleum in the 1920s as a cheap and convenient method of boosting octane ratings and reducing uneven ignition ("knocking") in combustion engines. When leaded petroleum is combusted in a motor vehicle engine, $>75 \%$ of lead is emitted from the exhaust as large particles which fall 
rapidly to the ground, while finer particles stay airborne for considerably longer periods of time (Eisenreich et al., 1986). By contrast, the exhaust from the predominantly twostroke motor boat fleet is generally discharged directly to water. Prior to 1986, New Zealand had one of the highest levels of lead in petrol $\left(0.84 \mathrm{~g} \mathrm{~L}^{-1}\right)$ of any nation (Taylor, 1998). Despite a reduction in 1986 to $0.45 \mathrm{~g} \mathrm{~L}^{-1}$, levels were still high compared with elsewhere. For example, most of Europe, including Britain, had reduced lead additives by 1986 to $0.15 \mathrm{~g} \mathrm{~L}^{-1}$ and the limit for the United States was $0.026 \mathrm{~g} \mathrm{~L}^{-1}$ (Taylor, 1998). A transition from leaded to unleaded petroleum took place in New Zealand between 1987 and 1996, resulting in almost complete elimination of airborne lead from the New Zealand environment (Wilson and Horrocks, 2008). In summary, except for a brief interruption in the 1940s, lead alkyl consumption in New Zealand increased steadily from the 1930s, plateaued between 1975 and 1986, and then decreased rapidly (Fig. 1).

Once lead has entered a lake, both specific asdorption and ion exchange mechanisms operate to transfer lead onto suspended sediments. The most significant sink for heavy metals in aerobic waters is scavenging by colloidal hydrous ferric and manganese oxides $\left(\mathrm{Fe}(\mathrm{OH})_{3}\right.$ and $\mathrm{MnO}_{2}$ ) (Harrison and Laxen, 1981). The sorption process is rapid and mostly irreversible, especially if the metal is incorporated with the hydrous oxide as it is precipitated. However, the adsorption is strongly $\mathrm{pH}$ dependent, increasing with an increase in $\mathrm{pH}$. Hydrous ferric and manganese oxides are readily reduced and become soluble under anaerobic conditions, and may release their associated metals. In eutrophic lakes the sediments ,may be anoxic for long periods, with sulfate (if sufficent is present) being reduced to sulfide, which removes any lead from the soluble phase via transformation to highly insoluble lead sulfide (Harrison and Laxen, 1981). In oligotrophic lakes the sediments may still be anoxic, but generally for brief periods of time and at much greater depth below the sediment-water interface, so that diagenetic immobilisation of lead will occur only deeper in the bottom sediments.

The aim of our study was to use sediments from a diverse set of lakes within the Rotorua region of New Zealand to indicate rates of environmental inputs of lead whilst taking into account differences of trophic state and lead exposure between the lakes. The lakes investigated range in trophic status from oligotrophic to highly eutrophic and also vary in exposure to leaded petroleum emissions (Table 1). The relatively isolated location and recent human settlement of New Zealand provided an opportunity to assess the geochemical transitions of lead in lake sediments associated with additions to petroleum. 


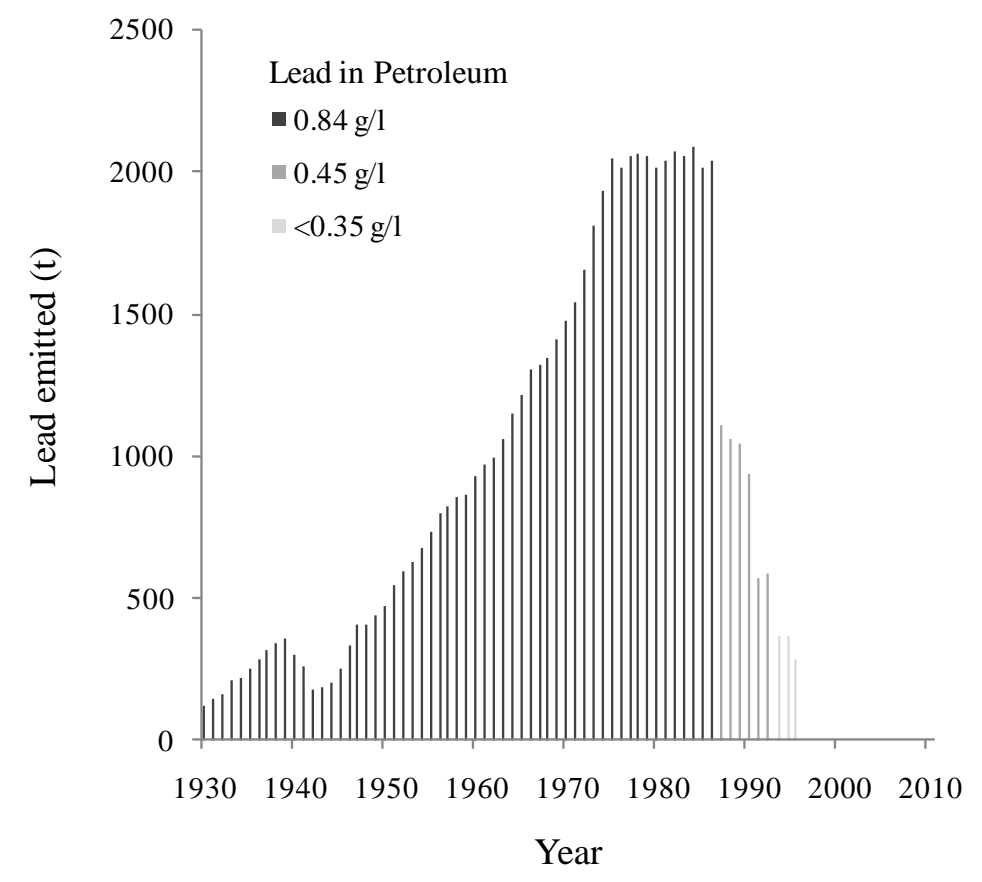

FIG. 1: Total amout of lead entering the New Zealand environment from petroleum consumption calculated by the total amount of petroleum consumed multiplied by the reported percentage of lead additive. Data from Statistics New Zealand (1960; L. Mackie, personal communication, February 17, 2009) and Ministry of Commerce (1996).

\section{Materials and Methods}

\subsection{Study sites}

The Rotorua lakes have been formed up to 140000 years ago from a series of volcanic eruptions that characterise the Taupo Volcanic Zone (TVZ) (Fig. 2) and have provided a series of stratigraphic markers for dating lake sediments (Lowe and Green, 1987). The most recent, the Tarawera tephra (arising from 10 June, 1886) is very distinctive in the sediment and can be easily distinguished visually within the top metre of sediment in all of the Rotorua Lakes. The tephra is described by Pullar and Kennedy (1981) as comprising of Tarawera scoria, a loose scoriaceous dark coloured coarse material underlying the Rotomahana mud, a grey to olive grey sandy to silty material. It is this upper extent of the Rotomahana mud layer that we term the 'depth to the Tarawera tephra'. The Rotorua District is still geothermically active, with lakes Rotorua, Rotoiti, Tarawera, Rotomahana and Rotoehu influenced by geothermal inflows (Vincent and Forsyth, 1987), which contribute significant sulfate to these lakes (Timperly and Vigor-Brown, 1986). 


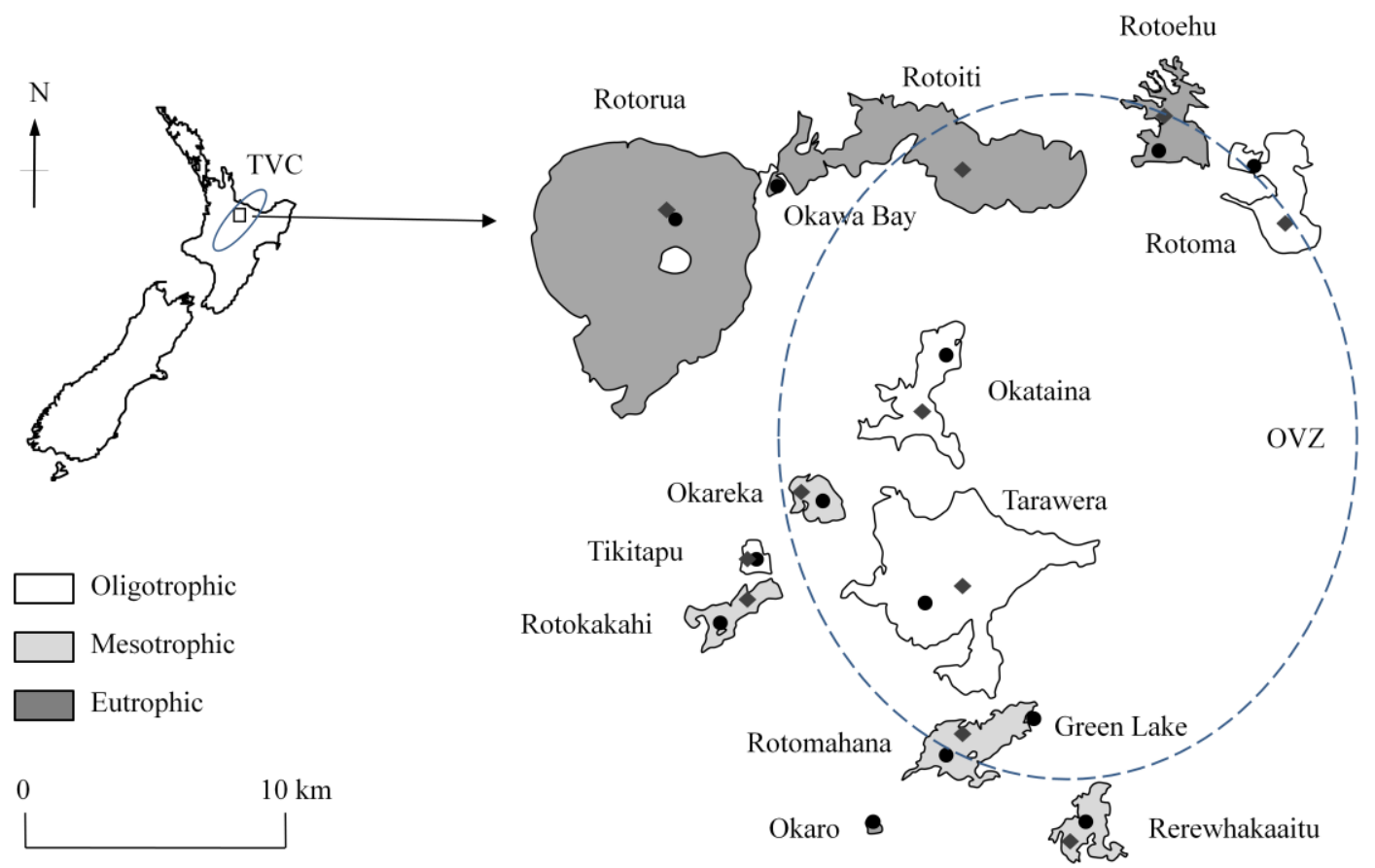

FIG. 2: Location of the Rotorua lakes, showing sample sites (marked with for core 1 and for core 2) and trophic status (shaded) of Rotorua lakes, within the Taupo Volcanic Centre (TVC) (solid line), New Zealand. The Okataina Volcanic Centre (OVC) is located in the Rotorua region and is shown by the dashed line. It is these volcanic centeres that are the source of the tephra layers used to date the sediment. Note only one core was collected in Green Lake.

The Rotorua lakes vary widely in trophic status (oligotrophic to highly eutrophic) and have two predominant mixing regimes; monomictic and polymictic (Table 1) (McColl, 1977; Burns et al., 1997; Trolle et al., 2008). Lake trophic status and silica availability are important controls on sedimentation rates (mainly diatom frustules where there is sufficient silica) and the extent of chemical reduction within the sediments (Trolle et al., 2008). A detailed chemical composition for the Rotorua lakes is given in Timperley and Vigor-Brown (1986). Sedimentation rates for the lakes are quoted from Trolle et al. (2008) who determined the depth to the Tarawera tephra in multiple cores taken from central deep basin of each of the lakes. They assumed a constant sedimentation rate since 1886. Where lakes have become more eutrophic subsequently, sedimentation rates can also be expected to increase, especially where diatoms predominate (Fish, 1969; Flint, 1977). 
TABLE 1: Physical characteristics of the Rotorua Lakes (McColl, 1975; Timperley, 1975; Burns et al., 1997; Trolle et al., 2008).

\begin{tabular}{|c|c|c|c|c|c|c|c|c|}
\hline Lake & $\begin{array}{l}\text { Mean depth } \\
(\mathrm{m})\end{array}$ & $\begin{array}{l}\text { Max.depth } \\
\quad(\mathrm{m})\end{array}$ & $\begin{array}{l}\text { Lake area } \\
\text { (ha) }\end{array}$ & $\begin{array}{l}\text { Catchment } \\
\text { area (ha) }\end{array}$ & $\begin{array}{c}\text { Sedimentation rate } \\
(1886-2006)\left(\mathrm{mm} \mathrm{y}^{-1}\right)\end{array}$ & $\begin{array}{l}\text { Trophic } \\
\text { state }\end{array}$ & $\begin{array}{l}\text { Mixing } \\
\text { Regime }\end{array}$ & $\begin{array}{c}\text { Potential } \\
\text { Lead Input }\end{array}$ \\
\hline Rotoma & 36.9 & 83.0 & 1104 & 2914 & $1.4(0.9-1.8)$ & Oligotrophic & M & Moderate \\
\hline Tarawera & 50.0 & 87.5 & 4165 & 14494 & $2.2(2.1-2.3)$ & Oligotrophic & M & Moderate \\
\hline Okataina & 39.4 & 78.5 & 1104 & 5676 & $1.4(1.4-1.4)$ & Oligotrophic & M & Low \\
\hline Tikitapu & 18.0 & 27.5 & 146 & 567 & $0.6(0.6-0.6)$ & Oligotrophic & M & High \\
\hline Rotokakahi & 17.5 & 32.0 & 452 & 1872 & $1.0(0.3-1.4)$ & Mesotrophic & M & Moderate \\
\hline Okareka & 20.0 & 33.5 & 342 & 1958 & $1.4(1.3-1.5)$ & Mesotrophic & M & Moderate \\
\hline Rerewhakaaitu & 7.0 & 15.8 & 579 & 3816 & $1.7(1.6-1.8)$ & Mesotrophic & $\mathrm{P}$ & Low \\
\hline Rotomahana & 60.0 & 125.0 & 897 & 7994 & $0.8(0.75-0.9)$ & Mesotrophic & M & Low \\
\hline Rotoiti & 31.5 & 124.0 & 3460 & 12462 & $1.7(1.7-1.7)$ & Eutrophic & M & High \\
\hline Rotoehu & 8.2 & 13.5 & 795 & 5673 & $2.6(2.6-2.6)$ & Eutrophic & $\mathrm{P}$ & Moderate \\
\hline Rotorua & 11.0 & 44.8 & 8079 & 52346 & $3.0(3.0-3.0)$ & Eutrophic & $\mathrm{P}$ & High \\
\hline Okaro & 12.5 & 18.0 & 32 & 407 & $2.3(1.5-2.8)$ & Highly Eutrophic & M & Moderate \\
\hline Green Lake & * & 26.2 & 1.12 & 2.16 & $*$ & Highly Eutrophic & $\mathrm{M}$ & Very Low \\
\hline
\end{tabular}

Foot note: * Some variables for Green Lake have not been determined.

Physical characteristics of the lakes from McColl (1975); Timperley (1975) and Burns et al. (1997). Sedimentation rate from Trolle et al. (2008) showing the mean value and range in parentheses. Trophic state is evaluated by Environment Bay of Plenty using the Trophic Level Index (TLI) (Burns et al., 2009). Potential lead exposure is rated by usage of the lake by motorised vessels, proximity to major roads and urban runoff. High input has been assigned to Lakes Rotorua and Rotoiti because of the density of settlement, extent of major roads and high usage by motor vessels. Tikitapu is a small lake used intensively for motorised water sports. Lakes Okataina, Rotomahana and Rerewhakaaitu have limited access, negligible urbanisation and motorised vessels are only occasionally encountered; they have been assigned low input.

\subsection{Sampling methods}

Sediments from thirteen Rotorua lakes; Rotoma, Tarawera, Okataina, Tikitapu, Okareka, Rotokakahi, Rerewhakaaitu, Rotomahana, Rotoiti, Rotoehu, Rotorua, Okaro and Green Lake, were sampled between March 2006 and January 2007. Two cores separated by a few metres were taken at a site near the deepest part of the central basin in each lake (Fig. 2; Table 2), targeting areas conforming to accumulation bottoms (cf. Håkanson and Jansson, 1983). Cores were taken with a Swedish gravity corer (Pylonex HTH $70 \mathrm{~mm}$ ) with a $60 \times 600 \mathrm{~mm}$ Perspex (Plexiglas) core barrel to capture undisturbed sediments. The gravity corer penetrated to a depth between c. 16 and $30 \mathrm{~cm}$ depending on the density of the sediment. The surface sediment was visually inspected in each core to determine if there was any disturbance at the sediment-water interface or in the sediment profile; the core was discarded and another core taken if the core was considered to have been disturbed during coring. A description of the core was recorded, including the depth to the Tarawera tephra. A custom made gas-tight sampling chamber, designed to minimise exposure of potentially anoxic sediment to the air, was fitted to the core barrel and, following retrieval, the core was extruded by a piston from the base of the core. Excess supernatant water overflowed the top of the core before the sediment sample was collected. Samples were extruded in $2 \mathrm{~cm}$ intervals and transferred 
into $50 \mathrm{~mL}$ polypropylene centrifuge tubes which were then sealed and placed on ice until return to the laboratory.

TABLE 2: Details of sediment cores taken for this study.

\begin{tabular}{lcccc}
\hline Lake & $\begin{array}{c}\text { Core } \\
\text { no. }\end{array}$ & $\begin{array}{c}\text { Water depth of sample } \\
\text { site }(\mathrm{m})\end{array}$ & $\begin{array}{c}\text { Depth to Tarawera } \\
\text { tephra }(\mathrm{mm})\end{array}$ & $\begin{array}{c}\text { Core sedimentation rate } \\
\left(\mathrm{mm} \mathrm{y}^{-1}\right)\end{array}$ \\
\hline Rotoma & 1 & 81.7 & 200 & 1.7 \\
Tarawera & 2 & 35.6 & 180 & 1.5 \\
Okataina & 1 & 82.2 & 260 & 2.2 \\
& 2 & 83.5 & 240 & 2.0 \\
Tikitapu & 1 & 69.1 & 160 & 1.3 \\
& 2 & 68.1 & 160 & 1.3 \\
Rotokakahi & 1 & 25.2 & 90 & 0.8 \\
& 2 & 25.4 & 90 & 0.8 \\
Okareka & 1 & 28.7 & 130 & 1.1 \\
& 2 & 28.6 & 130 & 1.1 \\
Rerewhakaaitu & 1 & 28.5 & 180 & 1.5 \\
& 2 & 24.8 & 140 & 1.2 \\
Rotomahana & 1 & 13.7 & 220 & 2.2 \\
& 1 & 10.0 & 260 & 0.8 \\
Rotoiti & 1 & 74.0 & 90 & 1.0 \\
& 2 & 74.0 & 120 & 2.5 \\
Rotorua & 1 & 64.9 & 300 & 1.4 \\
Rotoehu & 2 & 4.8 & 170 & 3.8 \\
Okaro & 1 & 18.4 & 460 & 3.8 \\
Green Lake & 2 & 18.4 & 460 & 2.5 \\
\hline
\end{tabular}

Footnote: Sedimentation rates calculated from depth to Tarawera tephra in the captured core.

In March 2007, a piston core was taken through progressively deeper sediments in Lake Rotorua to a depth of $8 \mathrm{~m}$ below the sediment surface in a water depth of 18.4 $\mathrm{m}$. The core was taken using a $3 \mathrm{~m}$ modified Livingstone piston coring system fed through a $15 \mathrm{~cm}$ diameter PVC pipe to guide the piston core to the same location on the lake bed for each successive core (Pickett, 2008). Sequential $3 \mathrm{~m}$ piston cores were extracted into longitudinally sectioned PVC tubes of the same diameter as the core barrel. As the piston coring method fails to capture the upper few $\mathrm{cm}$ of sediment an additional gravity core was collected adjacent to the piston core, and processed in the same way as the gravity cores from other lakes. This allowed the interpolation of the sediment record to the sediment-water interface. In the laboratory, the piston core was split using a wire cutter and the exposed core surface cleaned by scraping back to a uniform flat surface to ensure any sedimentary or structural features became evident and 
distinguishable from any features originating from the core splitting process. The core was then described and photographed (Pickett, 2008). Sediment samples of approximately $0.5 \mathrm{~cm}$ were cut from the core at $1 \mathrm{~cm}$ intervals to achieve a highresolution sediment record. Tephra horizons were recognised by textural and colour changes (white to pale grey), within the olive diatomaceous lake sediment (Table 3) and confirmed by x-ray imaging. The majority of the tephra layers exhibited primary depositional features with a sharp base that readily enabled recognition of the tephra extent and depth.

TABLE 3: Details of tephra located in the Lake Rotorua core.

\begin{tabular}{lcccccc}
\hline Tephra Name & Source & $\begin{array}{c}\text { Age } \\
(\text { Cal. yrs B.P.) }\end{array}$ & Year & $\begin{array}{c}\text { Depth in sed. } \\
(\mathrm{mm})\end{array}$ & $\begin{array}{c}\text { Inferred } \\
\text { sedimentation } \\
\text { rate }\left(\mathrm{mm} \mathrm{yr}^{-1}\right)\end{array}$ & $\begin{array}{c}\text { Tephra Pb } \\
\text { conc. }\left(\mu \mathrm{g} \mathrm{g}^{-1}\right)\end{array}$ \\
\hline Tarawera & OVC & 64 & $1886 \mathrm{AD}$ & $360-450$ & 3.3 & 8.80 \\
Reworked 1 & - & & & $2110-2126$ & & 3.40 \\
TgVC ash & TVC & & & $2190-2200$ & & 1.99 \\
Reworked 2 & - & & & $3880-3900$ & & 1.94 \\
Reworked 3 & - & & & $5010-5020$ & & 2.79 \\
Kaharoa & OVC & $636 \pm 12$ & $1314 \pm 12 \mathrm{AD}$ & $5040-5130$ & 3.45 & 2.40 \\
Taupo (Unit Y) & TVC & $1717 \pm 13$ & $233 \pm 13 \mathrm{AD}$ & $5670-5690$ & 0.48 & 1.63 \\
Waimihia (Unit S) + secondary & TVC & $3410 \pm 40$ & $1460 \mathrm{BC}$ & $6730-6750$ & 0.61 & 2.79 \\
Whakaipo tephra (Unit V) & & & & & & \\
Whakatane+secondary Unit K & OVC & $5530 \pm 60$ & $3580 \mathrm{BC}$ & $6950-$ & 0.12 & 0.84 \\
\hline
\end{tabular}

Foot note: Tephras were identified by on the basis of field appearance, stratigraphic position, ferromagnesian mineralogy, and major element glass chemistry (Pickett, 2008). Source shows the origin of tephra (Okataina Volcanic Centre, Taupo Volcanic Centre (Fig.2)). Age (Cal yrs. B.P) is the radiocarbon date with before present (B.P. 1950) taken from Lowe et al. (2008). Inferred sedimentation rate shows the rate of sediment accumulation between the tephra and the next overlying dated tephra. The Tarawera tephra shows the sedimentation rate for sediment accumulated since the eruption. The rate is calculated from comparison between both piston and gravity cores. The tephra lead concentration shows the maximum lead value present in the samples taken from the tephra layer.

\subsection{Analytical methods}

In the laboratory, the gravity core sediments were weighed to determine bulk density before porewaters were separated by centrifugation at $4000 \mathrm{rpm}$ for $40 \mathrm{~min}$. All sediments were dried at $105{ }^{\circ} \mathrm{C}$ for $24 \mathrm{~h}$ and ground using a mortar and pestle. Lead content of the sediment was determined after the solids had been digested with reverse aqua regia at $50{ }^{\circ} \mathrm{C}$ for one hour based on a modified standard procedure (Martin et al., 1994). The resulting digest was analysed using inductively coupled plasma mass spectrometry (ICP-MS model ELAN DRC II). The sediment dry weight fraction was determined by weighing solid samples before and after drying, and taking into account 
porewater mass. The pore water was filtered through a $0.45 \mu \mathrm{m}$ Millipore filter and acidified with nitric acid before analysis on ICP-MS as above. Scanning electron microscope (SEM) images were taken of the dried Lake Rotorua sediment before it was ground to assess the nature of the sediment. A detailed analysis of the composition of the sediment under SEM can be found in Pearson (2007) and Pickett (2008).

\section{Results and Discussion}

\subsection{Preindustrial lead}

An age model to identify pre-industrial sediment deposition in the Rotorua core was created from the thicknesses of biogenic material between tephras of known age (Whakatane (5530 \pm 60 cal. BP), Waimihia (3410 \pm 20 cal. BP), Taupo (1717 \pm 13 cal. BP), Kaharoa (c. AD $1314 \pm 12$ ) and the Tarawera eruption (AD 1886) (Balance, 1981; Newnham et al., 1998; Hogg et al., 2003; Lowe et al., 2008)) assuming constant sedimentation rates between eruption events. Tephra layers recorded as 'reworked' were not included in the age model as they are inferred to be caused by the reworking of coarse-grained tephra in shallower water, with these sediments deposited in the deeper lake basin during large storm events (c. 1300, 520 and 220 cal years B.P) (Pickett, 2008). The thickness of the reworked layers was accounted for in the determination of the sedimentation rate as these sediments are not biogenic material.

Lake Rotorua is antipodal to the preindustrial sources of atmospheric lead but still shows increases in lead concentrations from $<2$ up to $3.5 \mu \mathrm{g} \mathrm{g}^{-1}$ between the Whakatane eruption (5530 $\pm 60 \mathrm{cal}$. yrs BP) and the Tarawera eruption (Fig. 3). These changes parallel the trend of increases in lead observed in European and American lake sediments (Renberg et al., 1994; Graney et al., 1995; Monna et al, 1999; Renberg et al., 2002), but at much lower levels. Settle and Patterson (1980) concluded that because the residence time of atmospheric aerosols is an order of magnitude less than the interhemispheric exchange time, the impact in the Southern hemisphere from Northern hemisphere sources would be about one-tenth of that in the Northern Hemisphere; similar to fraction of lead in Lake Rotorua relation to the Northern Hemisphere lakes.

Concentrations of lead in the Rotorua core have local maxima centred around the tephra layers in pre-indrustiral sediments. Lead concentrations increase $\left(>2 \mu \mathrm{g} \mathrm{Pb} \mathrm{g}^{-1}\right)$ in the core commencing soon after deposition of the Tongariro tephra (age unknown but approximately $1700 \mathrm{AD}$ ), which may be related to a global increase in atmospheric lead levels (Settle and Patterson, 1980; Renberg et al., 1994) as there was no significant source of lead in New Zealand at this time of early Polynesian settlement. Globally, lead production has continued to increase since 5000 years BP and the concentration of lead in the sediments of Lake Rotorua mimics this global production trend (Fig. 3). An increase in lead concentrations, well above background levels or those of any of the tephras, occurred at a depth of $10 \mathrm{~cm}$ below the top of the core, where the peak is 14.1 $\mu \mathrm{g} \mathrm{Pb} \mathrm{g}^{-1}$ (Fig. 3). We attribute this peak to an increase in anthopogenic lead sources. 


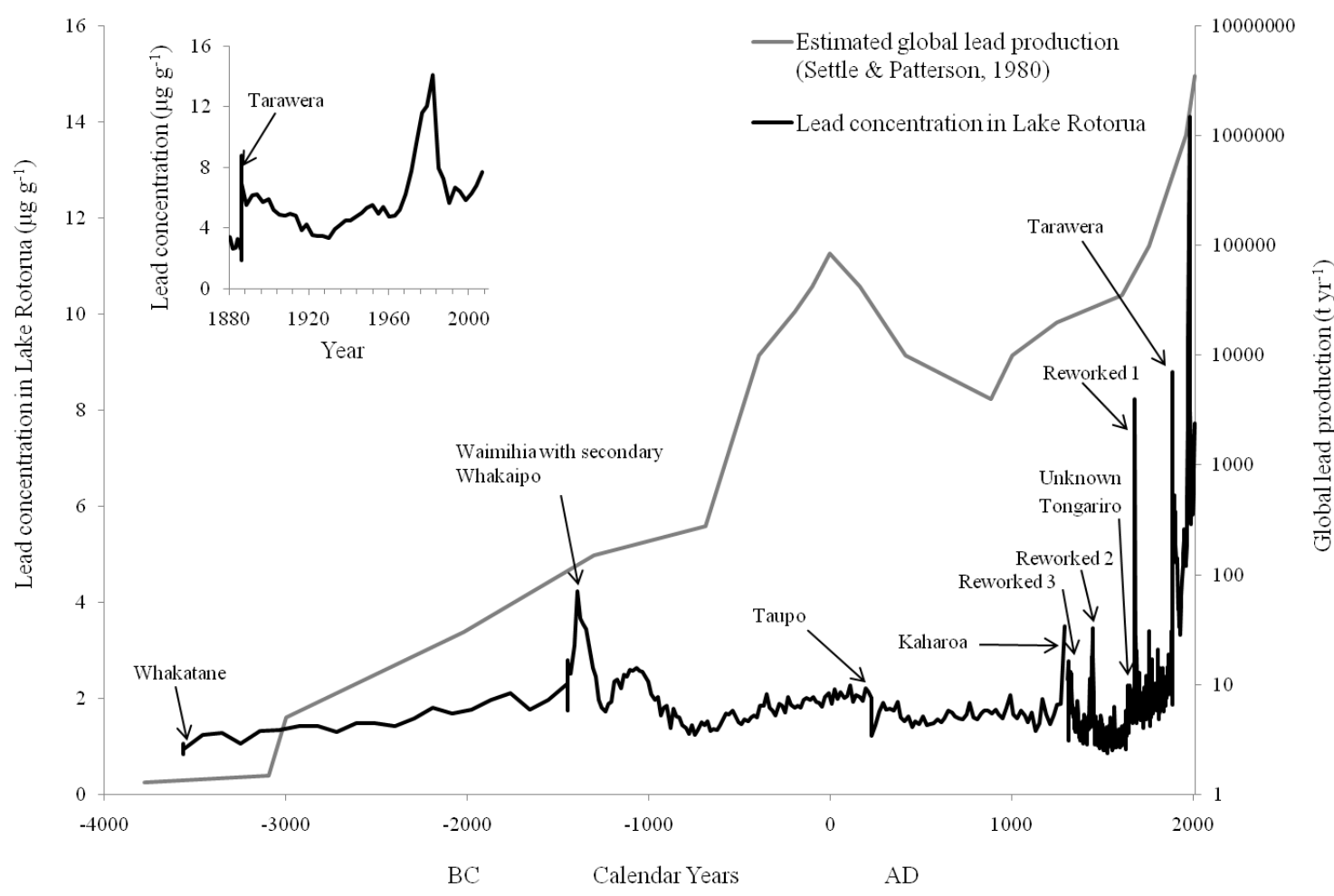

FIG. 3: Lead concentration in a Lake Rotorua sediment core with depositional age in excess of 5500 years on the left vertical axis. Global lead production for the same time period on the right vertical axis (Settle and Patterson, 1980). Annotations show volcanic events. Insert graph shows the lead concentration in Lake Rotorua for the period 1880 to present.

\subsection{Anthropogenic lead}

Identification of sediments likely to be impacted by local anthropogenic emissions is facilitated by the presence of the Tarawera tephra, which occurs in all of the Rotorua lakes. Sources of anthropogenic lead in the Rotorua lakes were negligible before the 1950s, peaked in the 1980s and declined during the 1990s, as lead was withdrawn from petroleum (Statistics New Zealand, 1960; L. Mackie, personal communication, February 17, 2009). Sediment profiles of the lead concentration in the Rotorua lakes all show a subsurface peak above the Tarawera tephra, with the exception of Green Lake (Fig. 4). The spatial variation between the sampling sites in the lakes is not significant with both profiles exhibiting similar results. Figure 5 shows a sediment profile of lead concentrations based on proportional age assuming a steady sedimentation rate since the Tarawera eruption (1886). The concentration and pattern of distribution of lead in the sediments of the Rotorua lakes show differences consistent with trophic status. Oligotrophic lakes (Fig. 5a) show a steady increase in lead concentrations since the Tarawera tephra, with a peak between 7 and $12 \mu \mathrm{g} \mathrm{g}^{-1}$ between 1950 and 1970, followed by a decline towards the sediment-water interface. Mesotrophic lakes (Fig. 4b) show a higher peak lead concentration (12-15 $\mathrm{gg} \mathrm{g}^{-1}$ ) between sediments aged 1970 and 1990, while eutrophic lakes, Rotoehu, Okaro and Rotoiti (Fig. 4c), show a peak in lead concentration up to $25 \mu \mathrm{g} \mathrm{g}^{-1}$ between 1920 and 1950, followed by a steady decline 
towards the sediment-water interface. Lakes with the lowest sedimentation rates (Tikitapu and Rotomahana; see Table 1) both have peak lead concentrations very close to the sediment surface. Peak concentrations of lead appear in sediments older than those corresponding to the peak discharge of lead to the environment. The extent of the displacement appears to be closely related to lake trophic status with the greatest displacement in the most eutrophic lakes.
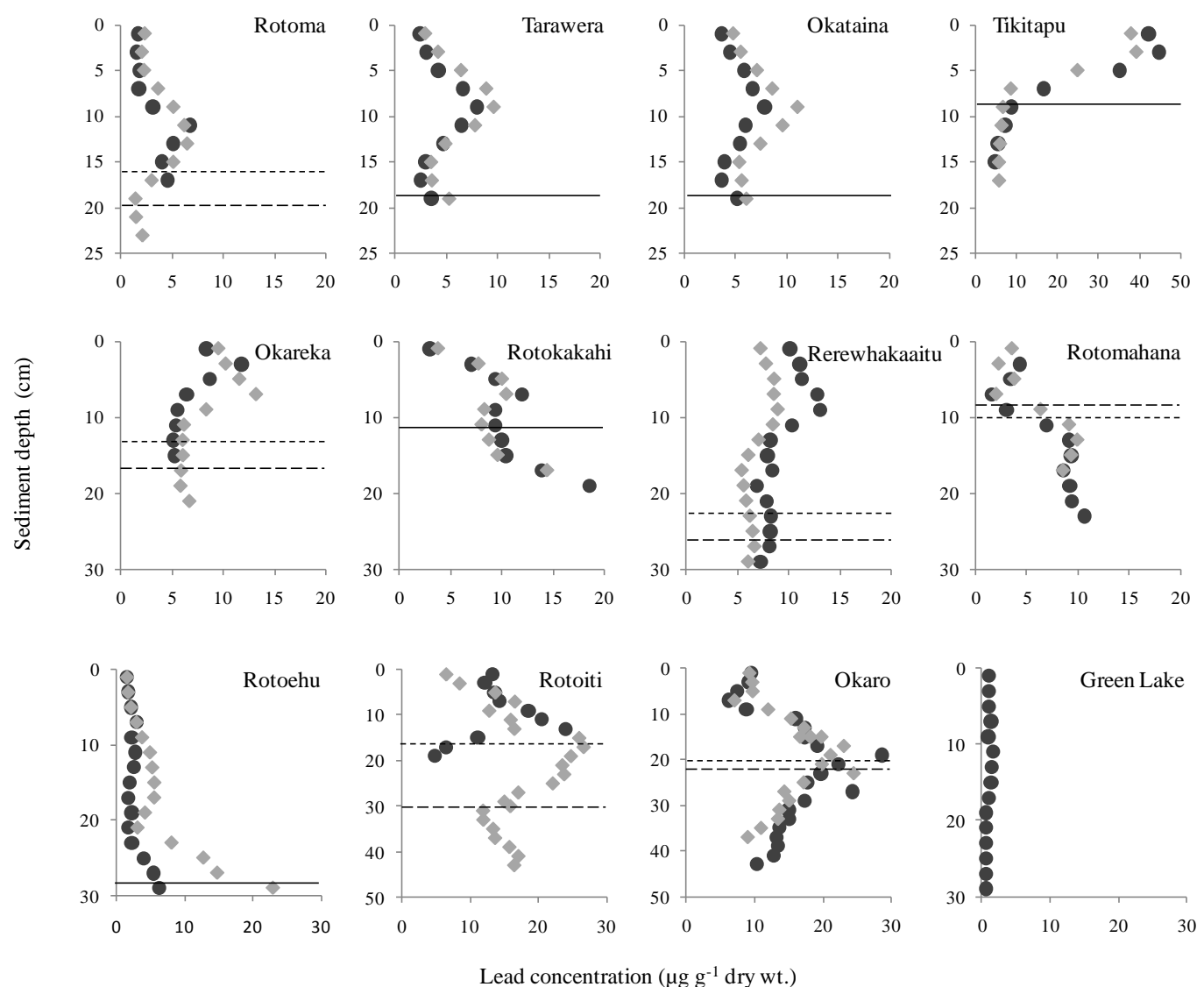

FIG. 4: Sediment concentration profiles of lead in the Rotorua lakes. Two cores (marked with and $\diamond$ ) were collected from the 13 lakes. Plots are arranged from oligotrophic to eutrophic (from left to right and top to bottom). If present in the core, the start of the Tarawera tephra layer, a layer of ash deposited during the $1886 \mathrm{AD}$ eruption, has been highlighted (marked with - - - for sites represented by - - for sites represented by $\diamond$, and —— where the tephra layer was present at the same vertical depth for both sites. The $\mathrm{y}$-axis represents depth below the sediment-water interface $(\mathrm{cm})$ and the $\mathrm{x}$-axis represents the lead concentration $\left(\mu \mathrm{g} \mathrm{g}^{-1}\right.$ dry wt.). Note the different scales for both axes. 

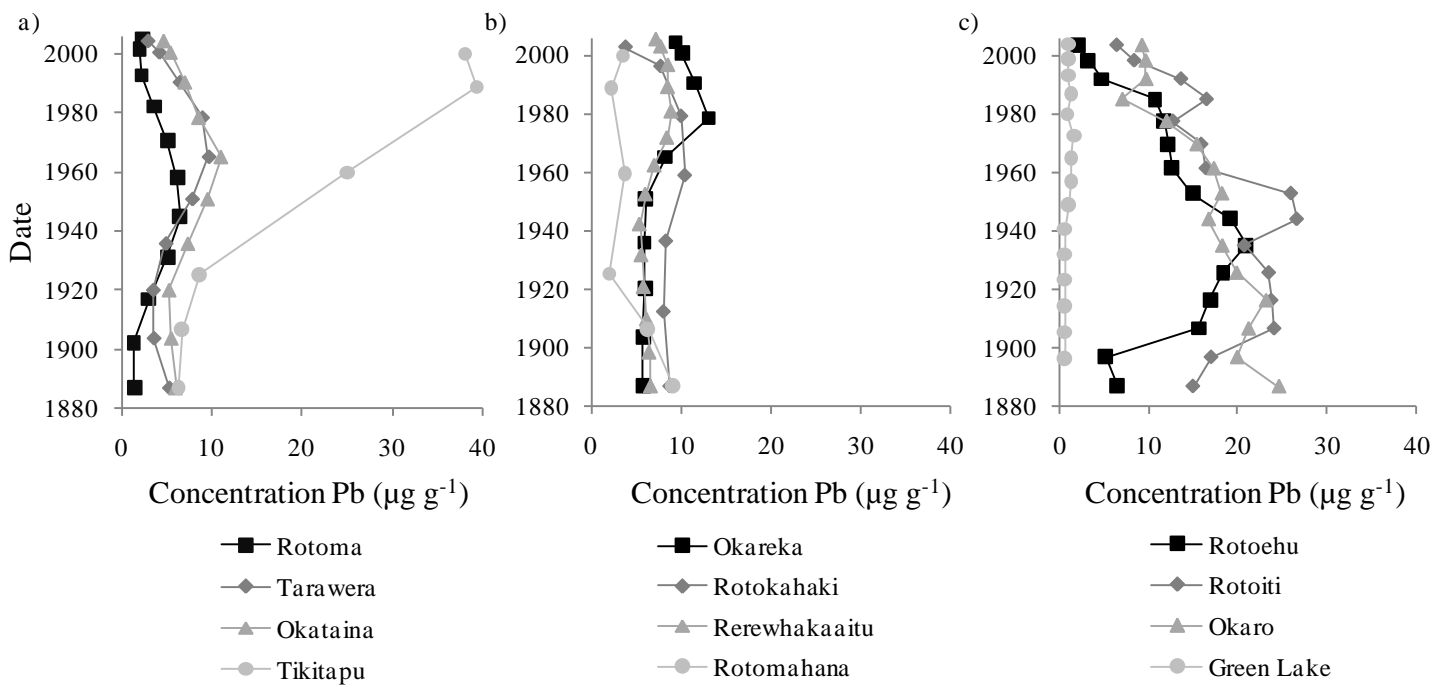

FIG. 5: Concentration of lead in sediment of a) oligotrophic lakes b) mesotrophic lakes and c) eutrophic lakes versus the sediment age calculated by the accumulation rate ( $\mathrm{mg} \mathrm{cm}^{-2} \mathrm{yr}^{-1}$ from bulk density) to the Tarawera tephra. Each data point represents a $2 \mathrm{~cm}$ slice of core.

\subsection{Redistribution of lead and diagenesis within lake sediments}

Lakes Rotorua, Rotoehu, Rotoiti and Okaro have become significantly eutrophied in recent decades (Burns et al., 2009), resulting in high rates of organic matter deposition (Trolle et al., 2009) and a peak lead concentration that is deeper in the sediment. In these lakes there is a broad distribution of elevated lead concentrations across the depth profile as a result of diagenesis and re-precipitation. Analyses of pore waters in these lakes typically show increasing concentrations of iron and manganese and decreasing concentrations of sulfur with depth below the sediment-water interface (Fig. 6). In many of the lake sediments, iron concentrations in the pore waters remain low and do not display systematic changes until sulfur concentrations are low. Scanning Electron Microscope (SEM) images of dried sediments from Lake Rotorua produced high densities of small framboidal clusters of pyrite that we suggest are indicative of supersaturation and precipitation of iron sulfides (Fig. 7). Energy dispersive x-ray fluorescence (XRF) analysis of the framboidal pyrite detected significant fluorescence's for sulphur, iron and minor fluorescence for lead. . Lead is most likely bound to the surfaces of diatom frustules and inorganic particle surfaces by iron or manganese hydroxides and oxy-hydroxides, as indicated by a high covariance between lead and iron $(r=0.98 \mathrm{p}<0.01)$, and lead and manganese $(r=0.93 \mathrm{p}<0.01)$ in the top $20 \mathrm{~cm}$ of sediment (Pearson, 2007). While the sediments remain oxidised, iron and manganese adsorption can be expected to maintain the lead in a particulate, immobile form (Sigg, 1985). With burial, the sediments of all of the lakes will become anoxic, which will induce reduction of manganese and iron, and mobilization of the lead. This effect is most pronounced in eutrophic lakes, with seasonally anoxic hypolimnia where sulfide generation in the sediments results in precipitation of lead sulfide, limiting the 
concentration of lead in the porewaters (Schindler, 1985). As sulfate reduction tends to occur deeper in the sediment than iron or manganese reduction, this process tends to redistribute lead from deeper in the sediments, reducing peak concentrations and smearing distributions across the depth profile as observed in Fig. 5.

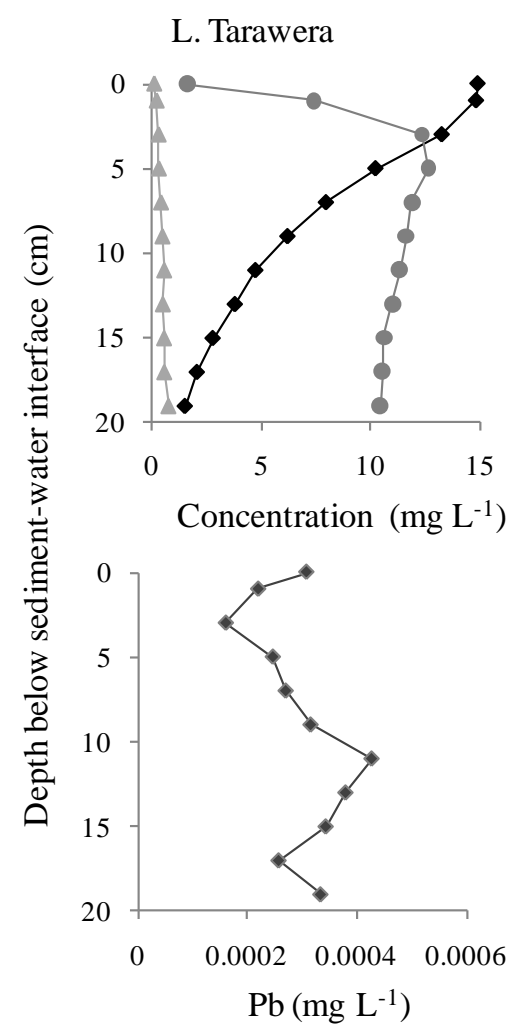

\section{Okataina}
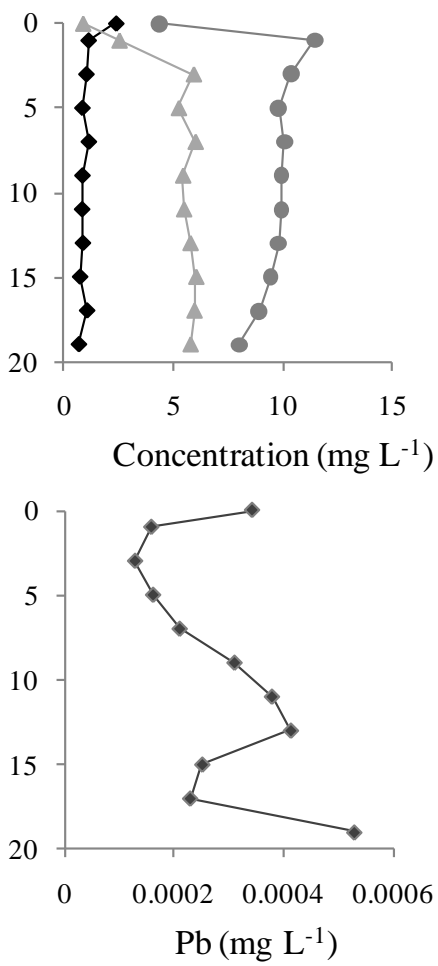

Lakes
L. Rotoiti

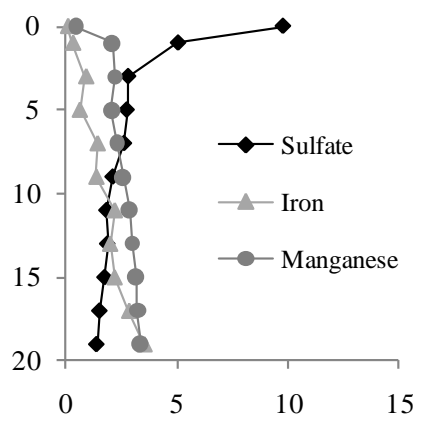

Concentration $\left(\mathrm{mg} \mathrm{L}^{-1}\right)$

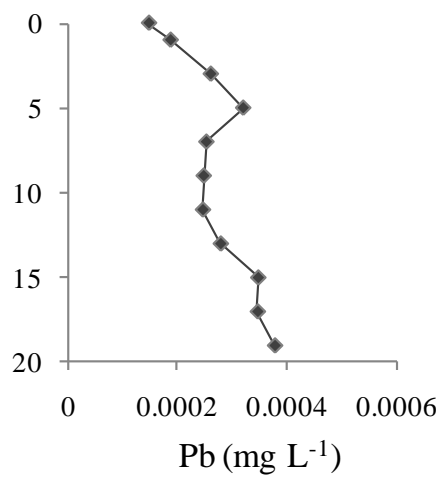

$\mathrm{Pb}\left(\mathrm{mg} \mathrm{L}^{-1}\right)$

FIG. 6: Mean annual concentrations of sulfur, iron, manganese and lead in porewaters of selected Rotorua Lakes. In a) Lake Tarawera the hypolimnion remains oxygenated the whole year, whereas in b) Lake Okataina the hypolimnion experiences seasonal anoxia during summer stratification (3 months) and in c) Lake Rotoiti the hypolimnion remains anoxic for half of the year (c. 6 months). 
a)

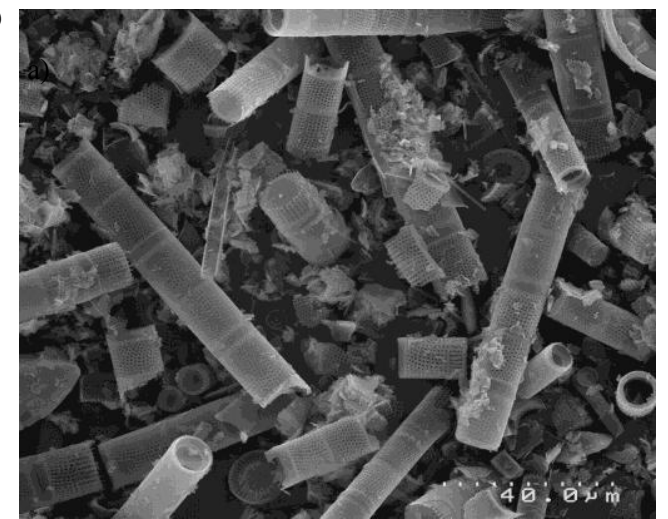

c)

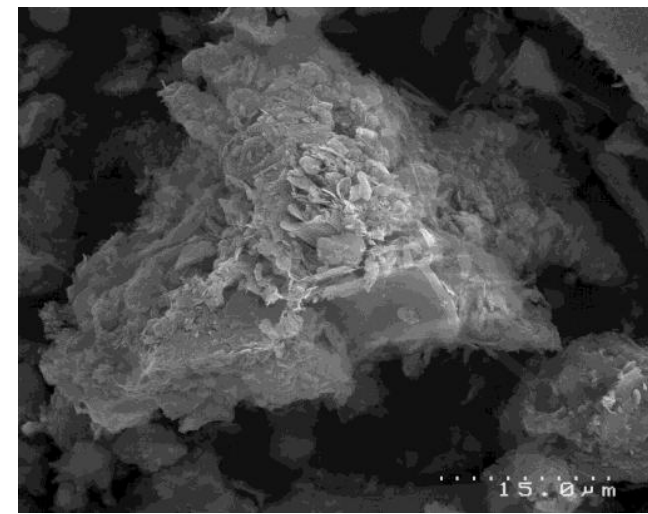

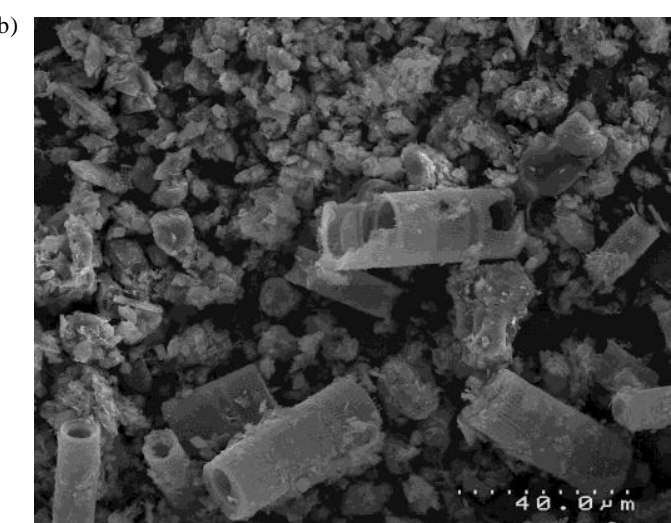

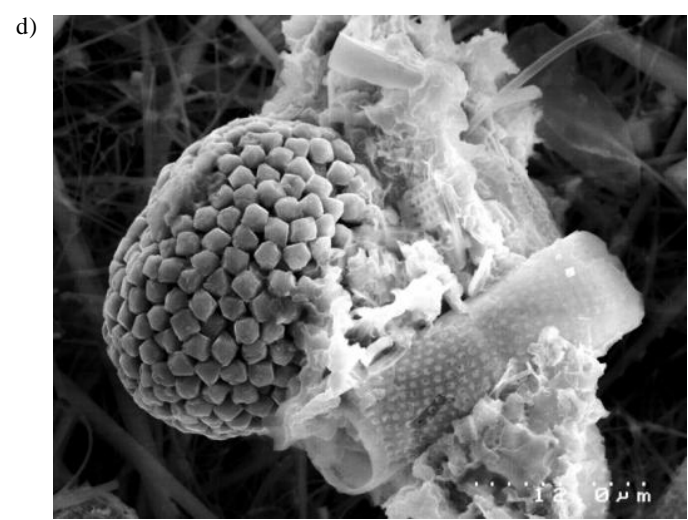

FIG. 7: Scanning Electron Microscope image of Lake Rotorua sediment showing a) the dominance of Aulacoseira granulata (diatom) frustules (cylindrical shape) over other diatom species and mineral particles, b) Rotomahana mud (Tarawera Tephra) erupted from Lake Rotomahana during the Tarawera eruption), c) increased magnification of Rotomahama mud layer showing the presence of diatoms within the mud layer and d) framboidal pyrite (upper left of foreground) and Aulacoseira granulata frustule.

\subsection{Lake Outliers}

Lakes Tikitapu, Rotomahana and Green Lake are outliers to the general pattern in other Rotorua lakes of occurrence of peak lead at a depth dependent on trophic status (Figs 4 and 5). Lake Tikitapu has a low concentration of reactive silicate (0.01-0.30 mg $\mathrm{Si} \mathrm{L}^{-1}$ ) (McColl, 1972), resulting in negligible representation of diatoms amongst the phytoplankton assemblage of this lake (Ryan, 2006). This lake has a correspondingly very low sedimentation rate $\left(0.6 \mathrm{~mm} \mathrm{yr}^{-1}\right.$; Trolle, 2008) and the lead peak is not resolved as a sub-surface peak at the $2 \mathrm{~cm}$ vertical sampling resolution used in this study. Modern Lake Rotomahana was created by the 1886 Tarawera eruption (Balance, 1981). It has a low sedimentation rate $\left(0.8 \mathrm{~mm} \mathrm{yr}^{-1}\right.$; Trolle et al., 2008, and $1 \mathrm{~mm} \mathrm{yr}^{-1}$ estimated from our study) and is inaccessible to the general public, limiting its exposure to anthropogenic lead sources. The accumulation of lead in Lake Rotomahana sediment is therefore likely to be largely through catchment erosion, dominated by the Rotomahana Mud unit of the Tarawera eruption, and atmospheric aerosols. The lake has high sulphate concentrations from geothermal inputs which are reduced in the sediment porewaters, preventing mobilisation of iron and lead through precipitation. The third outlier is Green Lake, which is a very small, highly eutrophic lake located $10 \mathrm{~m}$ from 
the shore of Lake Rotomahana. It was formed as an explosion crater during the Tarawera eruption (1886). The lake is totally inaccessible to motor boats and has negligible external catchment; groundwater and rainfall may contribute a substantial fraction of the total hydraulic load to the lake. Lead concentrations in the sediments of this lake are very low $\left(<2 \mu \mathrm{g} \mathrm{Pb} \mathrm{g}^{-1}\right)$ and comparable to prehistoric concentrations in Swedish lake sediments (Renburg et al., 1994), further suggesting that atmospheric deposition may be the dominant source of lead to the lake.

\section{Conclusions}

Leaded petroleum has had negative impacts on human health across the globe. Despite phasing out this chemical it is still widely distributed in the environment, accumulating in depositional areas such as lake sediments, where it can provide an historical marker of human use. In New Zealand, anthropogenic lead inputs to lakes are not contaminated by other industrial sources and, accounting for diagenetic processes, the sediment depositional layers therefore provide an accurate historical record of leaded petroleum usage. For the relatively recent period of pre-European settlement in New Zealand (late $18^{\text {th }}$ century) deeper sediments of the Rotorua lakes, corresponding to those deposited within this period, have low lead concentrations. In sediments above the Tarawera tephra layer there is a now a clearly identifiable stratum corresponding to anthropogenic lead from petroleum products. Variations between lakes are a function of exposure to leaded petroleum within the catchment and lake, as well as lake trophic state and redox status in lower water layers, which alters sedimentation rates and vertical transport of lead in the sediments. Diagenesis results in some redistribution of lead as iron and manganese are mobilised through oxidation and are immobilised by sulfate reduction to produce insoluble sulfides. The anthropogenic lead peak from lead alkyl petroleum additives can be expected to be buried rapidly, and is unlikely to affect the aquatic system unless sediments are significantly disturbed.

\section{Acknowledgements}

We acknowledge funding and field support from Environment Bay of Plenty and Hartley Contractors Ltd. Dennis Trolle provided sediment data and Annie Barker and Steve Cameron assisted with field work and ICP-MS analyses, respectively, at the University of Waikato. We also acknowledge Cornel E.J. de Ronde, GNS, Lower Hutt, $\mathrm{NZ}$, along with an anonymous reviewer for their valuable suggestions and comments on an earlier version of this paper. 


\section{References}

Balance, P.F., 1981. Geology and Landforms of the Rotorua Lakes Area, in: V.J. Chapman (Ed.), Handbook of the Rotorua Lakes District: The Guardians of the Rotorua Lakes. Rotorua, New Zealand. pp. 14-19.

Bindler, R., Renberg, I., Brännvall, M-L., Emteryd, O., El-Daoushy, F., 2001. A wholebasin study of sediment accumulation using stable lead isotopes and flyash particles in an acidified lake, Sweden. Limnol. Oceanogr. 46, 178-188.

Burns, N., McIntosh, J., Scholes, P., 2009. Managing the lakes of the Rotorua District, New Zealand. Lake Reservoir Manage. 25(3), 284 - 296.

Burns, N.M., Deely, J., Hall, J., Safi, K., 1997. Comparing past and present trophic status of seven Central Volcanic Plateau lakes, New Zealand. N. Z. J. Mar. Freshwater Res. 31, 71-87.

Chow, T.J., Bruland, K.W., Bertine, K., Soutar, A., Koide, M., Goldburg, E.D., 1973. Lead pollution: Records in Southern California coastal sediments. Science 181, 551552.

Davies, B.E., 1990. Lead, in: Alloway, B.J. (Ed.), Heavy Metals in Soils. Blackie and Sons Ltd., London, pp. 177-194.

Edgington, D.N., Robbins, J.A., 1976. Records of lead deposition in Lake Michigan sediments since 1880. Environ. Sci. Tech. 10, 266-274.

Eisenreich, S.J., Metzer, N.A., Urban, N.R., Robbins, J.A., 1986. Response of atmospheric lead to decreased use of lead in gasoline. Environ. Sci. Tech. 20, 171-174.

Fish, G.R., 1969. The oxygen content of some New Zealand lakes. Verh. Internat. Verein. Theor. Angew. Limnol. 17, 392-403.

Flint, E.A., 1977. Phytoplankton in several monomictic lakes near Rotorua, New Zealand. N.Z. J. Bot. 15, 197-208.

Graney, J.R., Halliday, J.R., Keeler, G.J., Nriagu, J.O., Robbins, J.A., Norton, S.A., 1995. Isotopic record of lead pollution in lake sediment from the north eastern United States. Geochim. Cosmochim. Acta 59(9), 1715-1728. 
Håkanson, L., Jansson, M., 1983. Principles of Lake Sedimentology, $2^{\text {nd }}$ edition. The Blackburn Press, New Jersey, 316 p.

Harrison, R.M., Laxen, D.P.H., 1984. Lead Pollution: Causes and Control. Chapman and Hall Ltd, London, 168p.

Hogg, A.G., Higham, T.F.G., Lowe, D.J., Palmer, J., Reimer, P., Newnham, R.M., 2003. A wiggle match date for Polynesian settlement of New Zealand. Antiquity 77, 116-125.

Hong, S., Candelone, J-P., Patterson, C.C., Boutron, C.F., 1994. Greenland ice evidence of hemispheric lead pollution two millennia ago by Greek and Roman civilizations. Science 265(5180), 1841-1843.

Lowe, D.J., Green, J.D., 1987. Origins and development of the lakes, in: Viner, A.B. (Ed.), Inland Waters of New Zealand, DSIR Bulletin 241. DSIR Science Information Publishing Centre, Wellington, pp. 1-64.

Lowe, D.J., Shane, P.A.R., Alloway, B.V., Newnham, R.M., 2008. Fingerprints and age models for widespread New Zealand tephra marker beds erupted since 30,000 years ago: a framework for NZ-INTIMATE. Quaternary Sci. Rev. 27, 95-126.

Martin, T.D., Creed, J.T., Brockhoff, C.A., 1994. Method 200.2 (Revision 2.8): sample preparation procedure for spectrochemical determination of total recoverable elements. in: Methods for the Determination of Metals in Environmental Samples. USEPA, Cincinnati, $\mathrm{OH}$.

McColl, R.H.S., 1972. Chemistry and trophic status of seven New Zealand lakes. N.Z. J. Mar. Freshwater Res. 6, 399-447.

McColl, R.H.S., 1975. Chemical and biological conditions in lakes of the volcanic plateau, in: Jolly, V.H., Brown, J.M.A. (Eds.), New Zealand Lakes. Auckland University Press, Auckland, pp. 123-139.

McColl, R.H.S., 1977. Chemistry of sediments in relation to trophic conditions in eight Rotorua lakes. N.Z. J. Mar. Freshwater Res. 11, 509-523.

Ministry of Commerce, 1996. Premium unleaded petrol: Detailed report on investigations into reported fuel system failures following the introduction of premium unleaded petrol. Ministry of Commerce, Wellington, New Zealand. 
Monna, F., Dominik, J., loizeau, J., Pardos, M., Arpagaus, P., 1999. Origin and evolution of $\mathrm{Pb}$ in sediments of Lake Geneve (Switzerland-France). Establishing a stable Pb record. Environ. Sci. Technol. 33, 2850-2857.

Murozuni, M., Chow, T.J., Patterson, C.C., 1969. Chemical concentrations of pollutant lead aerosols, terrestrial dusts and sea salts in Greenland and Antarctic snow strata. Geochim. Cosmochim. Acta 33, 1247-1294.

Newnham, R.M., Lowe, D.J., McGlone, M.S., Wilmshurst, J.M., Higham, T.F.G., 1998. The Kaharoa Tephra as a critical datum for earliest human impact in northern New Zealand. J. Archaeol. Sci. 25(6), 533-544.

Nriagu, J.O., 1998. Paleoenvironmental research: Tales told in lead. Science 281(5383), $1622-1623$.

Pearson, L.K., 2007. The nature, composition and distribution if sediment in Lake Rotorua, New Zealand. Unpubl. M.Sc. Thesis, University of Waikato, pp. 486.

Pickett, R.C., 2008. A tephra-dated record of palaeoenvironmental change since $~ 5,500$ years ago from Lake Rotorua, North Island, New Zealand. Unpubl. M.Sc. Thesis, University of Waikato, pp. 308.

Pullar, W.A., Kennedy, N.M., 1981. Tephra deposits in the Rotorua Lakes District, in: Chapman, V.J. (Ed), Handbook of the Rotorua Lakes District. The Guardians of the Rotorua Lakes, pp. 23-25.

Renberg, I., Persson, M.W., Emteryd, O., 1994. Pre-industrial atmospheric lead contamination detected in Swedish lake sediments. Nature 368, 323-326.

Renberg, I., Brännvall, M,-L., Bindler, R. and Emteryd, O., 2002, Stable lead isotopes and lake sediments - a useful combination for the study of atmospheric lead pollution history. Sci. Total Environ. 292, 45-54.

Rosman, K.J.R., Chisholm, W., Boutron, C.F., Candelone, J.P., Gorlach, U., 1993. Isotopic evidence for the source of lead in Greenland snow since the late 1960s. Nature 362, 333-335.

Ryan, E.F., 2006. Phytoplankton dynamics in North Island lakes, New Zealand. Unpubl. Ph.D. Thesis, University of Waikato, pp. 116. 
Schindler, D.W., 1985. The coupling of elemental cycles by organisms: evidence from whole-lake chemical perturbations, in: Stumm, W. (Ed.), Chemical Processes in Lakes. John Wiley, New York, pp. 225-250.

Settle, D. M., Patterson, C.C., 1980. Lead in Albacore: Guide to lead pollution in Americans. Science 207, 1167-1176.

Settle, D. M., Patterson, C.C., 1982. Magnitudes and sources of precipitation and dry deposition fluxes of industrial and natural leads to the North Pacific at Enewetak. J. Geophys. Res. 87, 8857-8869.

Shen, C.T., Boyle, E.A., 1987. Lead in corals: reconstruction of historical industrial fluxes to the surface ocean. Earth Planet. Sci. Lett. 82, 289-304.

Shotyk, W., Weiss, D., Appleby, P.G., Cheburkin, A.K., Frei, R., Gloor, M., Kramers, J.D., Reese, S., Van Der Knaap, W.O., 1998. History of atmospheric lead deposition since $12,370{ }^{14} \mathrm{C}$ yr BP from a peat bog, Jura Mountains, Switzerland. Science 281, $1635-1640$.

Sigg, L., 1985. Metal transfer mechanisms in lakes: the role of settling particles, in: Stumm, W. (Ed.), Chemical Processes in Lakes. John Wiley, New York, pp. 283-310.

Statistics New Zealand, 1960. New Zealand Official Yearbook 1960. Department of Statistics, R.E. Owen, Government Printer, Wellington, New Zealand.

Sturges, W.T., Barrie, L.A., 1989. Stable lead isotope ratios in Arctic aerosols: Evidence for the origin of Arctic air pollution. Atmos. Environ. 23, 2513-2519.

Taylor, B., 1988. Lead in petrol, in: Hay, J.E., de Mora, S.J. (Eds.), 1993. Lead in the New Zealand Environment: Proceedings of a Conference at the University of Auckland, August 12, 1988. Environmental Science Occasional Publication No. 9, Environmental Science, Auckland, pp. 80-89.

Timperley, M.H., 1975. Regional influences on lake water chemistry, in: Viner A.B. (Ed.), Inland Waters of New Zealand. DSIR Bulletin 241. DSIR Science Information Publishing Centre, Wellington. pp. 97-111. 
Timperley, M.H., Vigor-Brown, R.J., 1986. Water chemistry of lakes in the Taupo Volcanic Zone, New Zealand. N.Z. J. Mar. Freshwater Res. 20, 173-183.

Trolle, D., Hamilton, D.P., Hendy, C., Pilditch, C., 2008. Sediment and nutrient accumulation rates in sediments of twelve New Zealand lakes: influence of lake morphology, catchment characteristics and trophic state. Mar. Freshwat. Res., 59, 10671078.

Veron, A., Lambert, C.E., Isley, A., Linet, P., Grousset, F., 1987. Evidence of recent lead pollution in deep north-east Atlantic sediments. Nature 326, 278-281.

Vincent, W.F., Forsyth, D.J., 1987. Geothermally influenced waters, in: Viner, A.B. (Ed.), Inland Waters of New Zealand, DSIR Bulletin 241. DSIR Science Information Publishing Centre, Wellington. pp. 349-377.

Wilson, N., Horrocks, J., 2008. Lessons from the removal of lead from gasoline for controlling other environmental pollutants: A case study from New Zealand. Environ. Health 7, 1-10. 
